\title{
Young Indonesian Muslim women consumer behavior toward modest sportswear
}

\author{
Leonnard \\ Cut Sjahrifa \\ Citra Anggia Fathia \\ Daniya \\ Sekolah Tinggi Manajemen IPMI, Jakarta, Indonesia
}

\author{
Keywords \\ Consumer behavior, Modest sportswear, Muslim consumer, Theory of planned behavior
}

\begin{abstract}
Women modest sportswear has stepped up the industry of the modest fashion. The emerging economy, combined with the most significant Muslim population, has become the main attraction of Indonesia as a market for this particular fashion style. The purpose of this study is to determine motivating factors which affect the behavior of Indonesian Muslim women in buying modest sportswear by employing The Theory of Planned Behavior (TPB). Expectation, perception, the subjective norm, perceived behavioral control and consume's attitude toward modest apparel during sport, and purchase intention are the factors to be examined. By employing a Partial Least Squares Structural Equation Modelling (PLS-SEM), the analysis proclaimed that the effects of expectation, perception and the subjective norm on consumer's attitude toward modest apparel during sport are confirmed. The result given by perceived behavioral control on purchase intention is higher than the subjective norm. The subjective norm is also being confirmed to affect perceived behavioral control. Further managerial implications are discussed.
\end{abstract}

Corresponding author: Leonnard

Email addresses for the corresponding author: leonnard.ong@ipmi.ac.id

First submission received: $19^{\text {th }}$ October 2018

Revised submission received: $13^{\text {th }}$ December 2018

Accepted: 10 th January 2019

\section{The Introduction}

Modest fashion is one of the most promising industry. Thomson Reuters, in Collaboration with Dinar Standard (2017) estimated that the whole market was valued at USD 243 billion and projected to be USD 368 billion in 2021. From 2014 to 2015, the growth for modest fashion was $5.7 \%$, which was $2.2 \%$ higher than the global market growth. Indonesian spent approximately USD 13.28 billion in this category in 2015, and it was the fifth highest value in the world, after Turkey, United Arab Emirates, Nigeria, and Saudi Arabia. Indonesia composes of $12.7 \%$ of the world's Muslim population, which embeds it as the largest Muslim-majority country in the world. Approximately $87 \%$ of the country's total population is Muslim (CIA, 2016). Aside from the fact that modest apparel is mandatory for Muslim, the concept of modesty for activities that require agility such as sports is still limited. Sportswear's should be designed to deliver functions, comfort, and safety of its wearers, depicted by the usual sportswear that overthrow skin and body line exposure which conflict the Muslim women dress rules.

Despite the challenge, the modest sportswear market is very potential. The high desire of Muslim women to participate in any sport activity requires innovative sportswear, suitable fabric, and higher aesthetic values (Yazid, 2016). The well-known brands such as Nike and Marks \& Spencer, Veilgarments, Capsters, ResportOn, and Natasha are trying to penetrate this market (Yazid, 2016; Ahmed, 2017; Hosie, 2018). Besides the apparel designs, proper marketing strategies are required to lead the competition in the industry. An analysis of the purchasing behavior of modest sportswear is very potential to provide information and insights in terms of the motivation of young Muslim women to purchase modest sportswear. 
Although there are increasing number of studies discussing motivating factors affecting consumers' behavior of clothing products, sportswear, green shoes, and luxury goods (Nam, Dong, and Lee, 2017; Kim and Karpova, 2009; Ting, Goh, and Isa, 2016; and Xu, Chen, Burman, and Zhao, 2014) as well as halal products (Lada, Harvey Tanakinjal, and Amin, 2009; Hussain, Rahman, Zaheer, and Saleem, 2016; Khalek, 2014; Shah Alam, Mohd, and Hisham, 2011; and Briliana and Mursito, 2017). However, according to the knowledge of the authors, there are no studies that analyzed its effect on modest sportswear. Therefore, this study fills the gap of purchasing behavior of modest sportswear by examining the effect of expectation, perception, subjective norms, perceived behavioral controls, and consumers' attitudes toward modest apparel during sport.

\section{Literature Review}

\subsection{The Theory of Planned Behavior (TPB)}

The Theory of planned behavior (TPB) is the most widely used theory to explain the motivating factors that affect an individual to perform specified acts. This theory is a continuation of the Theory of Reasoned Action (TRA). According to this theory, the specific intention is influenced by the attitude toward the product, the subjective norm and the perceived behavioral control (Ajzen, 1991). The higher the individual's purpose toward a particular behavior, the higher the probability that the response will be performed. The use of this theory on fashion industry has been carried out in several products, such as fashion counterfeits (Kim and Karpova, 2009; Fernandes, 2013), luxury goods (Phau, Teah, and Chuah, 2015; Jain, Khan, and Mishra, 2017; Jain and Khan, 2017), green shoes and apparel (Nam, Dong, and Lee, 2017; Bong ko and Jin, 2017). Nam, Dong, and Lee (2017) modified the theory by providing expectation and perception variables following Tseng and Hung (2013) on green sportswear. The modification conforms to the consumer satisfaction model by Parasuraman, Zeithaml, and Berry (1985) where an individual will only be satisfied with a product if an individual perception of actual product's performance exceeds personal expectation. The satisfied individual will lead to purchase intention. Previous studies have proven this relationship (Leonnard, Daryanto, Sukandar, and Yusuf, 2015; Leonnard, 2017; Leonnard. 2018; Leonnard and Susilowati, 2018; Leonnard, 2018). Therefore, in this study, we adopted a modified theory of planned behavior with the contribution of expectation and perception selected from Nam, Dong, and Lee (2017) on modest sportswear.

\subsection{Expectation}

The expectation is a belief and expectation of an individual in terms of the benefits and advantages of a product that could be the resulted from prior purchases, word of mouth (WOM), or mass media (Lee, Lee, Chuang, and $\mathrm{Wu}, 2014)$. When consumers find the benefits are higher than their expectations after purchasing the products, satisfaction will generate. Conversely, when the perceived benefits are lower than their expectations, it will create dissatisfaction. Satisfaction will lead to positive attitudes toward products (Nam, Dong, and Lee, 2017; Leonnard and Susilowati, 2018; Leonnard and Susanti, 2018) and repurchase intention (Leonnard, 2018). Conversely, dissatisfaction will result in negative attitudes toward products and repurchase intention. In consideration of the prior research, the hypotheses to be tested are:

H1: Customer's expectation positively affects consumer's attitude toward modest sportswear.

H2: Customer's expectation positively affects consumer's purchase intention.

\subsection{Perception}

Perception is defined as the perception of actual product performance (Parasuraman, Zeithaml, and Berry, 1985; Zeithaml, 1988). The actual product performance is a consumer evaluation of the quality of the products they receive after purchase (Gronroos, 1982). The assessment may include evaluation of materials, facilities, human resources (Sasser, Olsen, and Wyckoff, 1978), technical or functional qualities (Gronroos, 1982), and 10 service quality dimensions suggested by Parasuraman, Zeithaml, and Berry (1985) including responsiveness, competence, access, courtesy, communication, credibility, security, understanding customers, and tangibles. In this study, the evaluation of product quality follows Parasuraman, Zeithaml, and Berry (1985) and Nam, Dong, and Lee (2017) consisting of tangibles and reliabilities. The previous studies have indicated a positive relationship between perception, consumer attitudes (Nam, Dong, and Lee, 2017; Diallo and Seck, 2018), purchase intention of apparel (Lee, Kim, 
Seock, and Cho, 2009; Erdil, 2015; Hsu and Hsu, 2017), purchase intention of counterfeit luxury goods (Kim and Karpova, 2010), and purchase intention of green shoes (Nam, Dong, and Lee, 2017). In consideration of the prior research, the hypotheses to be tested are:

H3: Customer's perception positively affects consumer's attitude toward modest sportswear.

H4: Customer's perception positively affects consumer's purchase intention.

\subsection{Subjective norms}

Subjective norms are social factors in the form of public, families, and respected people, which enforce someone into performing certain behaviors (Ajzen, 1991). It is necessary to consider the subjective norms as part of a power that affects specific considerations to make a purchase. Using modest apparel while doing any sport activity is considered to be one of the social controls for Muslim women. Mokhlis (2009) stated that religion is one of the social institutions that have the most significant impact in affecting the value and behavior of individuals. In the management and marketing perspectives, Muslim consumers tend to choose products that conform to their religious controls such as halal food (Khalek, 2014, Said et al., 2014), halal tourism (El-Gohary, 2015; Eid and El-Gohary, 2015) and halal cosmetics (Briliana and Mursito, 2017). In the case of sportswear, this study sets modesty as a criterion of sportswear selection for Muslim women.

Modest apparel is widely known as a way of dressing, which avoids sexual attraction (Oxford Dictionaries, 2017). In the study of the development and function of clothing and adornment, modesty becomes one of the theories of the origins of clothing. This theory argues that the original purpose of clothing is to conceal the genital organs from a sense of shame, embarrassment, or some other form of sexual emotion (Dunlap, 1928). One of the ways to see the evolving understanding of modest fashion is through the development of hijab. Hijab is one of the essential adornments of modest fashion. For example, in Pakistan, the influence of religion is still a powerful motivation for women to wear a hijab (Kamal and Fayyaz, 2016). An Egyptian also have the same perspective and even saw a veil as a form of gendered oppression. While for Yemeni women, they preferably see hijab as a part of their religious identity and culture (Jackson and Monk-Turner, 2015). On the other part of the world, Malaysian has a slightly shifting behavior, where a hijab becomes more of a determinant of their social status and the role of the veil as an adornment of faith have been decreasing (Hassim, 2017).

Based on our observation, we believe that most Indonesian women, especially the youth, are wearing hijab and modest apparel as a form of self-actualization. The basic theory of self-actualization came from Maslow's hierarchy of needs. Initially, the concept of this hierarchy explained that one should be able to fulfil the lower stage of need before reaching the self-actualization (Maslow, 1943) as well as Maslow convinced that the concept is not rigid, meaning one might have a different kind of hierarchy or might skip on some needs. Essentially, Maslow defined self-actualization as the maximization of one's most genuine potential. People who require self-actualization will try to develop a better version of themselves based on their independent preference and willingness. Therefore, self-actualization is a combination of personal growth and self-fulfilment (Maslow, 1987). Previous studies have indicated a positive relationship between subjective norms on perceived behavioral controls, consumers' attitudes toward products, and purchase intention on sportswear (Nam, Dong, and Lee, 2017, counterfeit luxury goods (Kim and Karpova, 2010), apparel (Han and Chung, 2014), and second-hand apparel (Xu, Chen, Burman, and Zhao, 2014). In this study, the dimensions of subjective norms followed Briliana and Mursito (2017). In consideration of the prior research, the hypotheses to be tested are:

H5: The subjective norm positively affects consumer's perceived behavioral control.

H6: The subjective norm positively affects consumer's attitude toward modest sportswear.

H7: The subjective norm positively affects consumer's purchase intention.

\subsection{Perceived behavioral control}

Perceived behavioral controls are resources and opportunity factors beyond the will of individuals that influence individual behavior (Ajzen, 1991; Ajzen, 2002). This concept exemplified that although consumers have a high desire to use modest sportswear, if they do not have access to the resources and opportunities to approach the product, in such way the purchase will never come after. Ajzen (2002), Kim 
and Karpova (2009), Nam, Dong, and Lee (2017), Briliana and Mursito (2017) have proven that perceived behavioral control positively affects consumers' attitudes toward products and purchase intention. In this study, the dimensions of perceived behavioral control followed Ajzen (2002). In consideration of the prior research, the hypotheses to be tested are:

H8: Perceived behavioral control positively affects consumer's attitude toward modest sportswear.

H9: Perceived behavioral control positively affects consumer's purchase intention.

\subsection{Attitude toward modest sportswear}

Attitudes toward behaviors are the tendency or consumer confidence toward products. A positive belief will result in expected behavior. This belief is generated from a series of attributes attached. In the theory of planned behavior, attitudes toward behaviors are influenced by subjective norms and perceived behavioral controls (Ajzen, 1991). Previous studies have also indicated positive relationships between attitude toward certain products to purchase intention as in sportswear (Nam, Dong, and Lee, 2017), counterfeit luxury goods (Kim and Karpova, 2009; Ting, Goh, and Isa, 2016), and second-hand apparel $(\mathrm{Xu}, \mathrm{Chen}, \mathrm{Burman}$, and Zhao, 2014). In this study, the dimensions of attitudes toward modest sportswear followed Briliana and Mursito (2017). In consideration of the prior research, the hypotheses to be tested are:

H10: Attitude toward modest sportswear positively affects consumer's purchase intention

The constellation of causality between variables and hypotheses to be tested is constructed in Figure 2 below. The latent and manifest variables used in the analysis are denoted in table A.1 (Appendix A.1).

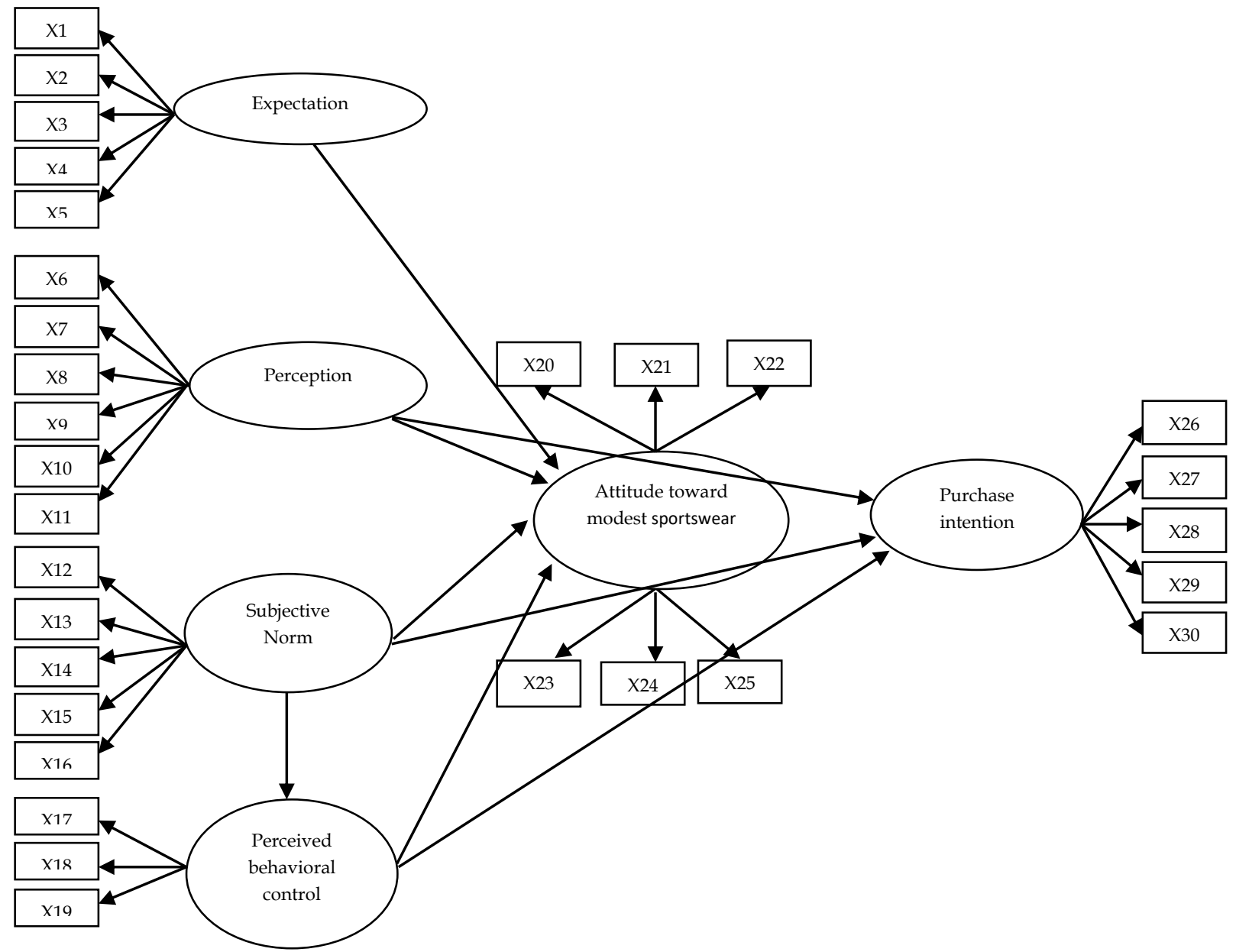

Figure 1: The proposed model of Indonesian young Muslim women consumer behavior toward modest sportswear 


\section{Research Methodology \\ 3.1 Samples}

In this study, we surveyed Muslim women that wear hijab with an age range from 18 to 30 years old in Greater Jakarta. Our respondents also need to have past experienced wearing modest sportswear. The questionnaires were distributed in gyms and sportswear retailers. As a result, a total of 65 respondents was employed in further analysis. The surveys were distributed through an online Google form, and it was provided along with a brief explanation in terms of the modest sportswear.

\subsection{Measurements}

This study was created upon on the TPB application on modest sportswear. There were six latent variables encompassed in the analysis. Specifically, the variables were expectation, perception, subjective norm, perceived behavioral control, attitude toward modest sportswear, and purchase intention adapted Nam, Dong, and Lee (2017). Dimensions of expectation were measured by following Lee, Lee, Chuang, and $\mathrm{Wu}(2014)$ while dimensions of perception were measured by following Parasuraman, Zeithaml, and Berry (1985). Dimensions of subjective norms and perceived behavioral control were measured by following Briliana and Mursito (2017). Ultimately, dimensions of purchase intention were measured by following Nam, Dong, and Lee (2017) and Briliana and Mursito (2017). Additional details of the dimensions were provided in Appendix A.1. All of the measurements were created by employing a 5point Likert scale $(1=$ strongly disagree; $5=$ strongly agree $)$.

\subsection{Data analysis}

Data analysis was processed by employing the PLS-SEM method through the SmartPLS 3.0 software package. The use of this method is appraised precisely because the number of samples in this study is relatively small. Therefore, the abnormal data distribution will cause covariance-based SEM analysis cannot be applied. The analysis of PLS-SEM was executed with the following steps: 1) Outer model analysis (evaluation of measurement model), and 2) Inner model analysis (evaluation of structural model) (Yamin and Kurniawan, 2011).

\section{Results}

\subsection{Evaluation of the outer model}

The results in table 1 below indicated that all indicators have high correlations with constructs. It is verified through the value of standardized loadings, which are $>0.5$ and $t$-statistics are $>2.0$. Besides, the evaluation of composite reliability and average variance extracted (AVE) indicated that convergent validity is confirmed. It is verified through the value of all of Cronbach's Alphas which are $>0.7$ and AVE $>0.5$.

Table 1: Outer loadings

\begin{tabular}{|c|c|c|c|c|c|c|c|}
\hline Constructs & Indicators & $\begin{array}{l}\text { Loading } \\
\text { factors }\end{array}$ & $\mathrm{t}$-Statistics & $\begin{array}{l}\text { Average } \\
\text { Variance } \\
\text { Extracted } \\
\text { (AVE) }\end{array}$ & $\begin{array}{l}\text { Composite } \\
\text { reliability }\end{array}$ & $\begin{array}{l}\text { Cronbach's } \\
\text { Alpha }\end{array}$ & $\begin{array}{l}\text { Rho } \\
\text { A }\end{array}$ \\
\hline \multirow[t]{5}{*}{ Expectation } & $\mathrm{X} 1$ & 0.782 & 14.627 & \multirow[t]{5}{*}{0.668} & \multirow[t]{5}{*}{0.909} & \multirow[t]{5}{*}{0.875} & \multirow[t]{5}{*}{0.879} \\
\hline & $\mathrm{X} 2$ & 0.808 & 17.976 & & & & \\
\hline & $\mathrm{X} 3$ & 0.813 & 14.801 & & & & \\
\hline & $\mathrm{X} 4$ & 0.880 & 29.712 & & & & \\
\hline & $\mathrm{X} 5$ & 0.801 & 13.239 & & & & \\
\hline \multirow[t]{6}{*}{ Perception } & $\mathrm{X} 6$ & 0.860 & 26.396 & \multirow[t]{6}{*}{0.641} & \multirow[t]{6}{*}{0.914} & \multirow[t]{6}{*}{0.886} & \multirow[t]{6}{*}{0.897} \\
\hline & $\mathrm{X} 7$ & 0.778 & 13.152 & & & & \\
\hline & $\mathrm{X} 8$ & 0.830 & 16.186 & & & & \\
\hline & $\times 9$ & 0.635 & 6.488 & & & & \\
\hline & $\mathrm{X} 10$ & 0.830 & 22.192 & & & & \\
\hline & $\mathrm{X} 11$ & 0.850 & 20.376 & & & & \\
\hline \multirow{2}{*}{$\begin{array}{l}\text { The subjective } \\
\text { norm }\end{array}$} & $\mathrm{X} 12$ & 0.757 & 11.618 & \multirow[t]{2}{*}{0.536} & \multirow[t]{2}{*}{0.851} & \multirow[t]{2}{*}{0.781} & \multirow[t]{2}{*}{0.793} \\
\hline & $\mathrm{X} 13$ & 0.668 & 8.125 & & & & \\
\hline
\end{tabular}




\begin{tabular}{|c|c|c|c|c|c|c|c|}
\hline & $\mathrm{X} 14$ & 0.825 & 21.171 & & & & \\
\hline & X15 & 0.761 & 12.399 & & & & \\
\hline & X16 & 0.632 & 7.575 & & & & \\
\hline \multirow{3}{*}{$\begin{array}{l}\text { Perceived } \\
\text { behavioral } \\
\text { control }\end{array}$} & X19 & 0.882 & 21.940 & \multirow[t]{3}{*}{0.736} & \multirow[t]{3}{*}{0.893} & \multirow[t]{3}{*}{0.819} & \multirow[t]{3}{*}{0.829} \\
\hline & $\mathrm{X} 21$ & 0.789 & 16.009 & & & & \\
\hline & $\mathrm{X} 22$ & 0.899 & 38.583 & & & & \\
\hline \multirow{6}{*}{$\begin{array}{l}\text { Attitude } \\
\text { toward Muslim } \\
\text { sportswear }\end{array}$} & $\mathrm{X} 23$ & 0.772 & 11.755 & \multirow[t]{6}{*}{0.636} & \multirow[t]{6}{*}{0.913} & \multirow[t]{6}{*}{0.885} & \multirow[t]{6}{*}{0.886} \\
\hline & $\mathrm{X} 24$ & 0.795 & 15.002 & & & & \\
\hline & $\mathrm{X} 25$ & 0.816 & 18.269 & & & & \\
\hline & $\mathrm{X} 26$ & 0.847 & 24.623 & & & & \\
\hline & $\mathrm{X} 27$ & 0.815 & 19.077 & & & & \\
\hline & $\mathrm{X} 28$ & 0.735 & 12.626 & & & & \\
\hline \multirow{5}{*}{$\begin{array}{l}\text { Purchase } \\
\text { intention }\end{array}$} & X30 & 0.560 & 5.111 & \multirow[t]{5}{*}{0.583} & \multirow[t]{5}{*}{0.873} & \multirow[t]{5}{*}{0.819} & \multirow[t]{5}{*}{0.854} \\
\hline & X31 & 0.726 & 10.915 & & & & \\
\hline & X32 & 0.823 & 14.909 & & & & \\
\hline & X33 & 0.852 & 22.954 & & & & \\
\hline & X34 & 0.818 & 15.392 & & & & \\
\hline
\end{tabular}

Furthermore, the evaluation of discriminant validity is executed by looking at the correlation between each indicator and its constructs. If the correlation is higher in its construct than the other constructs, then discriminant validity is confirmed. Table 2 indicated that discriminant validity is confirmed.

Table 2: Cross loading results

\begin{tabular}{|l|l|l|l|l|l|l|}
\hline & Expectation & Perception & $\begin{array}{l}\text { The } \\
\text { subjective } \\
\text { norm }\end{array}$ & $\begin{array}{l}\text { Perceived } \\
\text { behavioral } \\
\text { control }\end{array}$ & $\begin{array}{l}\text { Attitude } \\
\text { toward } \\
\text { muslim } \\
\text { sportswear }\end{array}$ & $\begin{array}{l}\text { Purchase } \\
\text { intention }\end{array}$ \\
\hline $\mathrm{X} 1$ & 0.782 & 0.505 & 0.610 & 0.507 & 0.654 & 0.495 \\
\hline $\mathrm{X} 2$ & 0.808 & 0.450 & 0.601 & 0.462 & 0.563 & 0.408 \\
\hline $\mathrm{X} 3$ & 0.813 & 0.642 & 0.634 & 0.653 & 0.618 & 0.549 \\
\hline $\mathrm{X} 4$ & 0.880 & 0.613 & 0.643 & 0.687 & 0.657 & 0.562 \\
\hline $\mathrm{X} 5$ & 0.801 & 0.448 & 0.574 & 0.598 & 0.591 & 0.497 \\
\hline $\mathrm{X} 6$ & 0.553 & 0.860 & 0.727 & 0.715 & 0.773 & 0.699 \\
\hline $\mathrm{X} 7$ & 0.478 & 0.778 & 0.663 & 0.646 & 0.645 & 0.548 \\
\hline $\mathrm{X} 8$ & 0.546 & 0.830 & 0.728 & 0.759 & 0.706 & 0.657 \\
\hline $\mathrm{X} 9$ & 0.367 & 0.635 & 0.620 & 0.499 & 0.479 & 0.559 \\
\hline $\mathrm{X} 10$ & 0.521 & 0.830 & 0.713 & 0.828 & 0.711 & 0.713 \\
\hline $\mathrm{X} 11$ & 0.621 & 0.850 & 0.765 & 0.819 & 0.760 & 0.765 \\
\hline $\mathrm{X} 12$ & 0.714 & 0.601 & 0.757 & 0.646 & 0.614 & 0.567 \\
\hline $\mathrm{X} 13$ & 0.619 & 0.540 & 0.668 & 0.531 & 0.671 & 0.585 \\
\hline $\mathrm{X} 14$ & 0.596 & 0.776 & 0.825 & 0.734 & 0.694 & 0.688 \\
\hline $\mathrm{X} 15$ & 0.459 & 0.716 & 0.761 & 0.619 & 0.610 & 0.592 \\
\hline $\mathrm{X} 16$ & 0.317 & 0.560 & 0.632 & 0.442 & 0.516 & 0.460 \\
\hline $\mathrm{X} 19$ & 0.630 & 0.818 & 0.721 & 0.882 & 0.708 & 0.623 \\
\hline $\mathrm{X} 21$ & 0.465 & 0.686 & 0.595 & 0.789 & 0.555 & 0.686 \\
\hline $\mathrm{X} 22$ & 0.730 & 0.801 & 0.790 & 0.899 & 0.742 & 0.739 \\
\hline $\mathrm{X} 23$ & 0.615 & 0.798 & 0.658 & 0.724 & 0.772 & 0.591 \\
\hline $\mathrm{X} 24$ & 0.560 & 0.711 & 0.680 & 0.629 & 0.795 & 0.599 \\
\hline $\mathrm{X} 25$ & 0.525 & 0.666 & 0.644 & 0.506 & 0.816 & 0.513 \\
\hline $\mathrm{X} 26$ & 0.627 & 0.698 & 0.724 & 0.672 & 0.847 & 0.590 \\
\hline $\mathrm{X} 27$ & 0.686 & 0.647 & 0.739 & 0.624 & 0.815 & 0.564 \\
\hline $\mathrm{X} 28$ & 0.600 & 0.561 & 0.628 & 0.576 & 0.735 & 0.610 \\
\hline $\mathrm{X} 30$ & 0.321 & 0.304 & 0.390 & 0.368 & 0.344 & 0.560 \\
\hline $\mathrm{X} 31$ & 0.471 & 0.490 & 0.567 & 0.506 & 0.442 & 0.726 \\
\hline & & & & & & \\
\hline
\end{tabular}

www.jbrmr.com A Journal of the Academy of Business and Retail Management (ABRM) 


\begin{tabular}{|l|l|l|l|l|l|l|}
\hline X32 & 0.516 & 0.676 & 0.663 & 0.696 & 0.557 & 0.823 \\
\hline X33 & 0.488 & 0.672 & 0.663 & 0.685 & 0.586 & 0.852 \\
\hline X34 & 0.532 & 0.820 & 0.724 & 0.769 & 0.748 & 0.820 \\
\hline
\end{tabular}

\subsection{Evaluation of inner model}

The further evaluation of the inner model indicated that expectation and perception of consumers' attitudes toward modest sportswear support hypotheses 1 and 3 (coeff. $=0.396$ and coeff. $=0.286$, respectively). Subjective norms significantly affect customer's attitudes toward modest sportswear, perceived behavioral control, and purchase intention supporting hypotheses 5, 6, and 7 (coeff. $=0.227$, 0.823 , and coeff. $=0.341$, respectively). Ultimately, perceived behavioral control significantly affects purchase intention supporting hypothesis 9 (coeff.= 0.434) (Table 3). All of the Variance Inflation Factor (VIF) scores are $<5$ and $\mathrm{R}^{2}$, which is explained by consumer's attitude toward modest sportswear is 81.5 $\%$, perceived behavioral control $67.8 \%$, and purchase intention $72.4 \%$.

Table 3: Direct, indirect, and total effects of PLS-SEM

\begin{tabular}{|c|c|c|c|c|}
\hline Hypotheses & Structural paths & $\begin{array}{l}\text { Direct } \\
\text { effects }\end{array}$ & $\begin{array}{l}\text { Indirect } \\
\text { effects }\end{array}$ & $\begin{array}{l}\text { Total } \\
\text { effects }\end{array}$ \\
\hline $\mathrm{H} 1$ & $\begin{array}{l}\text { Expectation -> Attitude toward modest apparel during } \\
\text { sport }\end{array}$ & $0.311^{* *}$ & - & $0.311^{* *}$ \\
\hline $\mathrm{H} 2$ & Expectation -> Purchase intention & -0.050 & \begin{tabular}{|l|}
-0. \\
002 n.s
\end{tabular} & -0.052 \\
\hline H3 & $\begin{array}{l}\text { Perception -> Attitude toward modest apparel during } \\
\text { sport }\end{array}$ & $0.606^{* * *}$ & - & $0.606^{* * *}$ \\
\hline $\mathrm{H} 4$ & Perception -> Purchase intention & 0.162 & $\begin{array}{l}-0 . \\
004 \text { n.s }\end{array}$ & 0.158 \\
\hline H5 & $\begin{array}{l}\text { The subjective norm -> Attitude toward modest apparel } \\
\text { during sport }\end{array}$ & $0.227^{*}$ & $\begin{array}{l}-0 . \\
140 \text { n.s }\end{array}$ & 0.087 \\
\hline H6 & The subjective norm -> Perceived behavioral control & $0.823^{* * *}$ & - & $0.823^{* * *}$ \\
\hline H7 & The subjective norm -> Purchase intention & $0.341^{* *}$ & $0.357^{* *}$ & $0.698^{* *}$ \\
\hline $\mathrm{H} 8$ & $\begin{array}{l}\text { Perceived behavioral control } \rightarrow \text { Attitude toward } \\
\text { modest apparel during sport }\end{array}$ & -0.170 & - & -0.170 \\
\hline $\mathrm{H} 9$ & Perceived behavioral control -> Purchase intention & $0.434^{* *}$ & $0.001 n . s$ & $0.435^{* *}$ \\
\hline H10 & $\begin{array}{l}\text { Attitude toward modest apparel during sport -> } \\
\text { Purchase intention }\end{array}$ & -0.006 & - & -0.006 \\
\hline
\end{tabular}

Note: $n$. $s=$ non-significant at alpha $0.05 ;{ }^{* * *} \mathrm{p}<0.01 ;{ }^{* *} \mathrm{p}<0.05 ;{ }^{*} \mathrm{p}<0.10$

\section{Discussions}

The results indicated that expectation and perception are confirmed directly to affect consumers' attitudes toward modest apparel during sport. These results support the prior study of Nam, Dong, and Lee (2017). Expectation and perception of modest sportswear can escalate consumer confidence and tend to wear modest apparel during sport. However, these two variables do not result in purchase intention of modest sportswear directly. It is inconsistent with Ajzen (1991), Nam, Dong, and Lee (2017), Kim and Karpova (2010), Ting, Goh, and Isa, 2016), Xu, Chen, Burman, and Zhao (2014) and Briliana and Mursito (2017). According to Nam, Dong, and Lee (2017), it is because young Muslim women have different perceptions of modest wear during sport. They may choose an alternative to using modest apparel during sport but do not buy modest sportswear individually, or it can be because they still want to use conventional sportswear even though they understand about the influence of subjective norms, especially the rules of decency. These results are further supported by hypothesis 10. It is proved that a customer's attitude toward modest apparel during sport does not significantly affect consumer's purchase intention.

Subsequently, the effect of perception on attitudes toward modest apparel during sport is higher than expected. Perception is an assessment of consumers post purchase of modest sportswear. Consumers who are satisfied with the quality of modest sportswear will have absolute confidence in modest sportswear. These results are consistent with Nam, Dong, and Lee (2017) and Diallo and Seck (2018). The 
subjective norm also influences a consumer's attitude, perceived behavioral control, and purchase intention. The result is consistent with Kim and Karpova (2010), Xu, Chen, Burman, and Zhao (2014), Nam, Dong, and Lee (2017). The subjective norm in this study is a way of dressing which avoids sexual attraction per the Muslim woman's identity and religious control as a social institution. The courtesy norm is a crucial aspect of being an indicator of modest sportswear. The higher the influence of perceived norms of religion, people around, the development of the fashion industry and the popularity of the products, the higher the consumer attitudes, perceived behavioral control and consumer purchase intention to modest sportswear would be. The relationship between each construct is indicated in Figure 2 below.

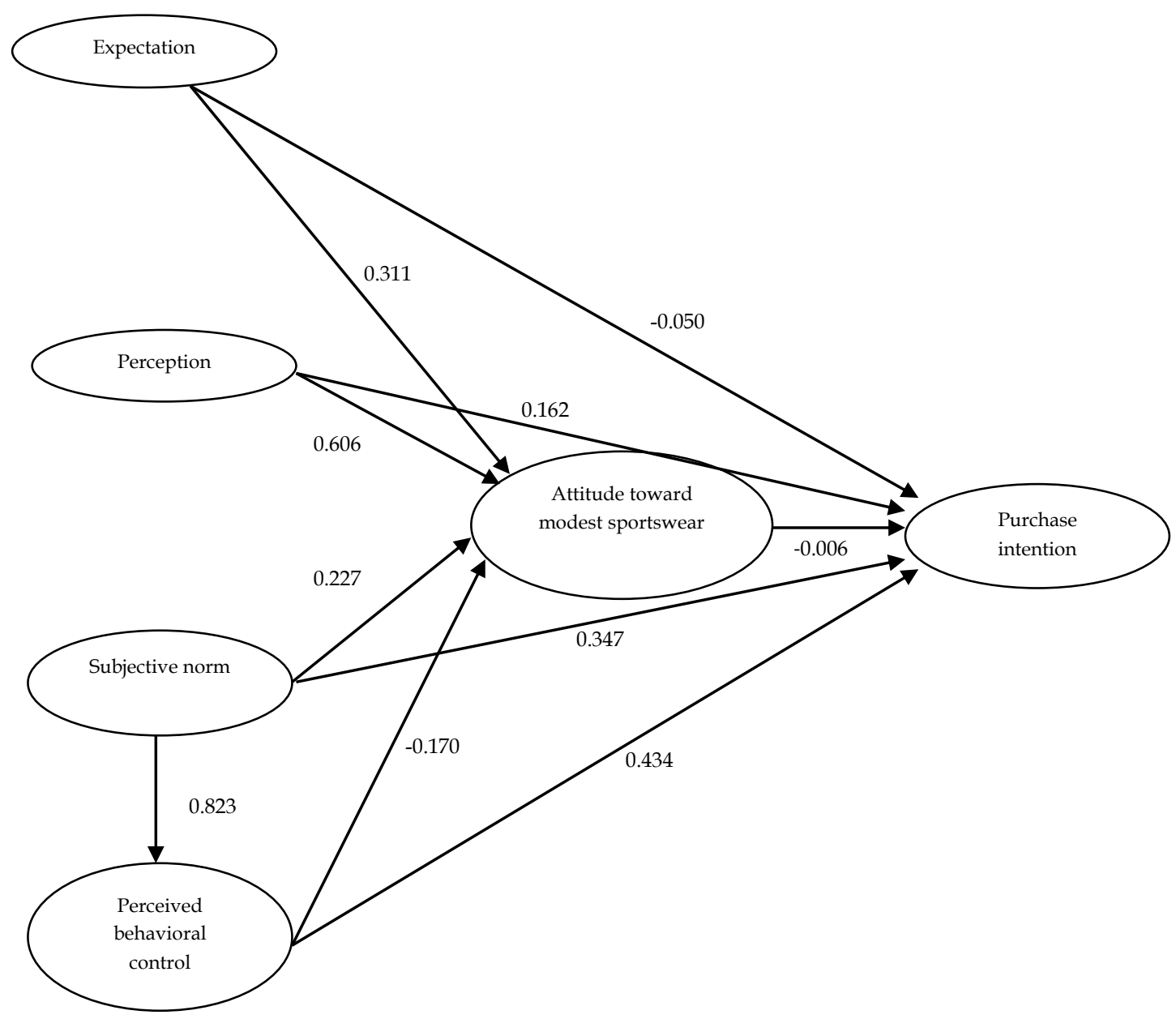

Figure 2: Structural path of PLS-SEM

Note: $n$. $s=$ non-significant at alpha 0.05

The results in table 3 indicate that subjective norms affect purchasing intention directly. Even though without the support of opportunities and resources (perceived behavioral controls) and consumer attitudes, young women in this study will be expected to make purchases of modest sportswear. As stated by Briliana and Mursito (2017), religion is not only regarded as a personal affair, but also as an essential aspect of politics and the social environment. This influence also exhibited a significant market share for modest sportswear in Indonesia. However, the effect of subjective norms of this research is generally from the perspective of norms of decency for individuals and others, as well as the development of fashion 
trends displayed by influencers as stated by Hassim (2014). Further studies are expected genuinely in terms of the aspect of religiosity as recommended by Briliana and Mursito (2017).

Moreover, in terms of coefficient magnitude, the direct influence of perceived behavioral controls over purchase intention is higher (coeff. $=0.434$ ) than subjective norms (coeff. $=0.341$ ) indicating opportunities, ownership, and access to resources for modest sportswear have a more critical role for Muslim women in Indonesia. They will create modest sportswear purchases if the required resources are accessible. The condition has been described by Nam, Dong, and Lee (2017). Perceived behavioral controls do not significantly affect consumers' attitudes toward modest apparel during sport. It is consistent with Nam, Dong, and Lee (2017). According to Nam, Dong, and Lee (2017), this is indeterminate because young Muslims women's attitude to fashion apparels when exercising is not only influenced by money and information of their willingness. On the other hand, perceived behavioral control proved to affect purchase intention directly. It is consistent with Nam, Dong, and Lee (2017), Kim and Karpova (2009), and Nam, Dong, and Lee (2017).

Indonesia has an enormous number of Muslim populations with young women aged 18 to 50 reaching approximately 35 million people (Briliana and Mursito, 2017). This large amount provides a vast market potential for modest sportswear. As reported by the Indonesian Ministry of Trade in 2014, sportswear covered $18 \%$ of the total market share of apparel in Indonesia (Salim and Ernawati, 2015). This study provides an essential motivating factor affecting purchase intention of modest sportswear for young Muslim women in Indonesia. Expectation, perception, the subjective norm, and perceived behavioral controls are the key factors that significantly affect the purchase intention. Of the total variables, the subjective norm has the highest influence. An essential point of this variable is that the modest sportswear manager can use influencers such as local designers, selegrams, or Indonesian female athletes. It is expected to affect the purchase intention rate directly.

Moreover, the Indonesian government does not impose any ban or discrimination on female athletes who want to use modest sportswear at certain sports activities (Damayanti and Rahayu, 2017). Following the subjective norms, another important variable is the perception of real performance after wearing modest sportswear. As mentioned in the previous discussion, perception in this study is defined as the quality of products offered by the company.

\section{Conclusions}

The findings of this study confirmed the significant effects of expectation, perception and the subjective norm on consumer's attitude toward modest apparel during sport. The subjective norm and perceived behavioral control affect purchase intention with the effect given by perceived behavioral control are higher. Moreover, the subjective norm also affects perceived behavioral control. Unlike the previous studies, we found that perceived behavioral control does not significantly affect consumer's attitude toward modest apparel during sport. Consumer's attitude toward fashion apparel during sport was found to have no significant influence on purchase intention.

\section{Limitations and Direction for Future Research}

The results of this study provide benefits for modest sportswear manufacturers considering the vast market potential existing. Expectation, perception, subjective norms, and perceived behavioral controls are key factors to be acknowledged. Of the total variables, subjective norms have the highest effect, as managers can use promotional media through influencers such as local designers, selebgrams, or Indonesian female athletes. However, promoted products must be able to deliver high quality and match the needs of users while exercising. For further research, it is advisable to contribute variables that measure about the sportswear itself, such as fashion knowledge, fashion patronage stores, local brand confidence, and fashion shopping styles as proposed by Chui, Nik, and Amzan (2017). 


\section{Appendix}

Table A.1: Variables and attributes employed in the study

\begin{tabular}{|c|c|c|}
\hline $\begin{array}{l}\text { Latent } \\
\text { variables }\end{array}$ & Labels & Manifest variables \\
\hline \multirow{5}{*}{ Expectation } & $\mathrm{X} 1$ & The modest sportswear that I use will represent myself well. \\
\hline & $\mathrm{X} 2$ & $\begin{array}{l}\text { The modest sportswear that I use will represent my sports activities } \\
\text { well. }\end{array}$ \\
\hline & $\mathrm{X} 3$ & $\begin{array}{l}\text { Wearing the modest sportswear will enact more comfortable in } \\
\text { exercising. }\end{array}$ \\
\hline & $\mathrm{X} 4$ & Wearing the modest sportswear will enact more spirit in exercising. \\
\hline & $\mathrm{X} 5$ & Wearing modest sportswear will increase my intensity for exercising. \\
\hline \multirow[t]{6}{*}{ Perception } & $\mathrm{X} 6$ & The modest sportswear has an attractive design and shape \\
\hline & $\mathrm{X} 7$ & The modest sportswear has an attractive colour choice \\
\hline & $\mathrm{X} 8$ & The modest sportswear has a high-quality material \\
\hline & X9 & $\begin{array}{l}\text { The ambience and design of the stores (online and offline) of the modest } \\
\text { sportswear are very convenient }\end{array}$ \\
\hline & $\mathrm{X} 10$ & The modest sportswear has a high quality \\
\hline & $\mathrm{X} 11$ & $\begin{array}{l}\text { The modest sportswear provides fabric information or product features } \\
\text { on each product }\end{array}$ \\
\hline \multirow[t]{5}{*}{$\begin{array}{l}\text { The subjective } \\
\text { norm }\end{array}$} & $\mathrm{X} 12$ & $\begin{array}{l}\text { The modest sportswear that I wear represents the value of courtesy } \\
\text { according to the religion that I believe }\end{array}$ \\
\hline & $\mathrm{X} 13$ & $\begin{array}{l}\text { In choosing the modest sportswear, I am influenced by developments in } \\
\text { the fashion industry }\end{array}$ \\
\hline & $\mathrm{X} 14$ & The value of decency is one of the reasons I wear the modest sportswear \\
\hline & $\mathrm{X} 15$ & $\begin{array}{l}\text { Recommendations from others influenced my decision in purchasing } \\
\text { the modest sportswear }\end{array}$ \\
\hline & $\mathrm{X} 16$ & $\begin{array}{l}\text { The effect of the popularity of the product is substantial to my decision } \\
\text { in purchasing the modest sportswear. }\end{array}$ \\
\hline \multirow{3}{*}{$\begin{array}{l}\text { Perceived } \\
\text { behavioral } \\
\text { control }\end{array}$} & $\mathrm{X} 19$ & I can buy the modest sportswear \\
\hline & $\mathrm{X} 21$ & Lots of information is available on the modest sportswear \\
\hline & $\mathrm{X} 22$ & I wear modest sportswear because of my desires. \\
\hline \multirow{6}{*}{$\begin{array}{l}\text { Attitude } \\
\text { toward } \\
\text { modest } \\
\text { sportswear }\end{array}$} & $\mathrm{X} 23$ & I am interested in the modest sportswear \\
\hline & $\mathrm{X} 24$ & I need the modest sportswear \\
\hline & $\mathrm{X} 25$ & The modest sportswear is substantial to me. \\
\hline & $\mathrm{X} 26$ & I feel comfortable using the modest sportswear \\
\hline & $\mathrm{X} 27$ & I feel the modest sportswear I wear works well \\
\hline & $\mathrm{X} 28$ & I am satisfied with the modest sportswear design that I wear \\
\hline \multirow{5}{*}{$\begin{array}{l}\text { Purchase } \\
\text { intention }\end{array}$} & $\mathrm{X} 30$ & I will always buy the modest sportswear as my sportswear \\
\hline & $\mathrm{X} 31$ & I will recommend the modest sportswear to the people around me. \\
\hline & $\mathrm{X} 32$ & $\begin{array}{l}\text { I am willing to seek information from various sources to get the modest } \\
\text { sportswear that I favour }\end{array}$ \\
\hline & $\mathrm{X} 33$ & $\begin{array}{l}\text { I am willing to wait and spend a long time to get the modest sportswear } \\
\text { that I favour }\end{array}$ \\
\hline & $\mathrm{X} 34$ & I will repurchase the modest sportswear \\
\hline
\end{tabular}

\section{References}

Ahmed, S. (2017) Nike's Pro Hijab: a great leap into modest sportswear, but they are not the first [Online]. Available at: https://www.theguardian.com/sport/blog/2017/mar/08/nike-performance-hijab-female-muslim-athletes (Accessed: 31 May 2018).

Ajzen, I. (1991) 'The theory of planned behavior', Organizational behavior and human decision processes, 50(2), pp. 179211.

Ajzen, I. (2002) 'Perceived behavioral control, self-efficacy, locus of control, and the theory of planned behavior 1', Journal of applied social psychology, 32(4), pp. 665-683. 
Bong Ko, S. and Jin, B. (2017) 'Predictors of purchase intention toward green apparel products: A cross-cultural investigation in the USA and China', Journal of Fashion Marketing and Management: An International Journal, 21(1), pp. 70-87.

Briliana, V. and Mursito, N. (2017) 'Exploring antecedents and consequences of Indonesian Muslim youths' attitude toward halal cosmetic products: A case study in Jakarta', Asia Pacific Management Review, 22(4), pp. 176-184.

Chui, C. T. B., Nik, N. S. and Azman, N. F. (2017) 'Making sense of fashion involvement among Malaysian Gen Y and its implications', Journal of Emerging Economies E Islamic Research, 5.

CIA. (2016) The World Fact Book [Online]. Available at: https://www.cia.gov/library/publications/the-worldfactbook/geos/id.html (Accessed: 31 May 2018).

Damayanti, I. and Rahayu, N. I. (2017) 'The effect of Muslim women's sportswear (Jilbab) to dehydration level and thermoregulation after exercise'. IOP Conference Series: Materials Science and Engineering, 180(1), pp. 012204.

Diallo, M. F. and Seck, A. M. (2018) 'How store service quality affects attitude toward store brands in emerging countries: Effects of brand cues and the cultural context', Journal of Business Research, 86, pp. 311-320.

Dunlap, K. (1928) 'The development and function of clothing', The Journal of General Psychology, 1(1), pp. 64-78.

Eid, R. and El-Gohary, H. (2015) 'The role of Islamic religiosity on the relationship between perceived value and tourist satisfaction', Tourism Management, 46, pp. 477-488.

El-Gohary, H. (2016) 'Halal tourism, is it really halal?', Tourism Management Perspectives, 19, pp. 124-130.

Erdil, T. S. (2015) 'Effects of customer brand perceptions on store image and purchase intention: An application in apparel clothing', Procedia-Social and Behavioral Sciences, 207, pp. 196-205.

Fernandes, C. (2013) 'Analysis of counterfeit fashion purchase behavior in UAE', Journal of Fashion Marketing and Management: An International Journal, 17(1), pp. 85-97.

Gronross, C. (1990) Strategic management and marketing in the service sector, Research Reports No. B, Swedish School of Economics and Business Administration, Helsinki.

Han, T. I. and Chung, J. E. (2014) 'Korean consumers' motivations and perceived risks toward the purchase of organic cotton apparel', Clothing and Textiles Research Journal, 32(4), pp. 235-250.

Hassim, N. (2014) 'A comparative analysis on hijab wearing in Malaysian Muslimah magazines', Journal South East Asia Rese. Center Comm. and Humanities, 6, pp. 79-96.

Hassim, N. (2017) 'Glocalizing' the hijab: A Malaysian perspective'. SHS Web of Conferences, 33, pp. 00016.

Hosie, R. (2018) Marks \& Spencer's modest clothing for women faces heavy criticism [Online]. Available at: https://www.independent.co.uk/life-style/fashion/marks-spencer-modest-clothing-range-women-shamingfeminism-name-a8147576.html (Accessed: 31 May 2018).

Hsu, Y. and Hsu, W. J. (2017) 'The impact of crossover clothing brand on consumer purchase intention', International Review of Management and Business Research, 6(1), pp. 105.

Hussain, I., Rahman, S. U., Zaheer, A. and Saleem, S. (2016) 'Integrating factors influencing consumers' halal products purchase: Application of theory of reasoned action', Journal of international food $\mathcal{E}$ agribusiness marketing, 28(1), pp. 35-58.

Jain, S., Khan, M. N. and Mishra, S. (2017) 'Understanding consumer behavior regarding luxury fashion goods in India based on the theory of planned behavior', Journal of Asia Business Studies, 11(1), pp. 4-21.

Jain, S. and Khan, M.N. (2017) 'Measuring the impact of beliefs on luxury buying behavior in an emerging market: Empirical evidence from India', Journal of Fashion Marketing and Management: An International Journal, 21(3), pp. 341-360.

Jackson, K.E. and Monk-Turner, E. (2015) 'The meaning of hijab: Voices of Muslim women in Egypt and Yemen', Journal of International Women's Studies, 16(2), pp. 30-48.

Kamal, A. and Fayyaz, W. (2016) 'Conditions of wearing hijab and other forms of dress: a comparative study', Pakistan Journal of Women's Studies, 23(2).

Khalek, A. A. (2014) 'Young consumers' attitude toward halal food outlets and JAKIM's halal certification in Malaysia', Procedia-Social and Behavioral Sciences, 121, pp. 26-34.

Kim, H. and Karpova, E. (2010) 'Consumer attitudes toward fashion counterfeits: Application of the theory of planned behavior', Clothing and Textiles research journal, 28(2), pp. 79-94.

Lada, S., Harvey Tanakinjal, G. and Amin, H. (2009) 'Predicting intention to choose halal products using theory of reasoned action', International Journal of Islamic and Middle Eastern Finance and Management, 2(1), pp. 66-76.

Lee, Y., Kim, S., Seock, Y. K. and Cho, Y. (2009) 'Tourists' attitudes toward textiles and apparel-related cultural products: A cross-cultural marketing study', Tourism Management, 30(5), pp. 724-732.

Lee, C. K., Lee, Y. C., Chuang, Y. S. and Wu, W. L. (2014) 'The effect of electronic word-of-mouth, customer expectations, and emotions on intention to take low cost airlines', Advanced Approaches to Intelligent Information and Database Systems, pp. 69-75. 
Leonnard, L., Daryanto, H. K., Sukandar, D. and Yusuf, E. Z. (2015) 'The loyalty model of private university student', International Research Journal of Business Studies, 7(1).

Leonnard, L. (2017) 'Measuring grocery stores service quality in Indonesia: a retail service quality scale approach', Studies and Scientific Researches. Economics Edition, 26.

Leonnard (2018) 'The performance of servqual to measure service quality in private university', Journal on Efficiency and Responsibility in Education and Science, 11(1), pp. 16-21.

Leonnard, L. and Susilowati, E. (2018) 'Electronic word of mouth (E-WoM) of transportation application consumers in Indonesia: Which factors that are matter', Esensi: Jurnal Bisnis dan Manajemen, 8(1).

Leonnard, S.E. (2018) 'Perceived service quality, perceived value for money, satisfaction and repurchase intention: an evaluation on private university services', International Journal of Commerce and Finance, 4(1), pp. 40-51.

Leonnard and Susanti, Y. F. (2019) 'The advocacy model of Indonesian Chinese students, The affluent market', International journal of instruction, 12(1).

Maslow, A. H. (1943) 'A theory of human motivation', Psychological review, 50(4), pp. 370.

Maslow, A. H. (1987) Motivation and personality (Revised by R. Frager, J. Fadiman, C. McReynolds \& R. Cox). NY: Harper \& Row.

Mokhlis, S. (2009) 'Relevancy and measurement of religiosity in consumer behavior research', International Business Research, 2(3), pp. 75.

Nam, C., Dong, H. and Lee, Y. A. (2017) 'Factors influencing consumers' purchase intention of green sportswear', Fashion and Textiles, 4(1), pp. 2.

Oxford dictionaries. (2017) Definition of modest in English [Online]. Available at: https://en.oxforddictionaries.com/definition/modest (Accessed: 18 May 2018).

Parasuraman, A., Zeithaml, V. A. and Berry, L. L. (1985) 'A conceptual model of service quality and its implications for future research', The Journal of Marketing, pp. 41-50.

Phau, I., Teah, M. and Chuah, J. (2015) 'Consumer attitudes toward luxury fashion apparel made in sweatshops', Journal of Fashion Marketing and Management, 19(2), pp. 169-187.

Said, M., Hassan, F., Musa, R. and Rahman, N. A. (2014) 'Assessing consumers' perception, knowledge and religiosity on Malaysia's halal food products, Procedia-Social and Behavioral Sciences, 130, pp. 120-128.

Salim, Z., and Ernawati. (2015) Apparel commodity information (Info komoditi pakaian jadi) [Online]. Available at: bppp.kemendag.go.id/media_content/.../Isi-BRIK_Pakaian_Jadi.pdf (Accessed: 18 May 2018).

Sasser, W. E., Olsen, R. P. and Wyckoff, D. D. (1978) Management of service operations: Text, cases, and readings. Allyn \& Bacon.

Shah Alam, S., Mohd, R. and Hisham, B. (2011) 'Is religiosity an important determinant on Muslim consumer behavior in Malaysia?' Journal of Islamic Marketing, 2(1), pp. 83-96.

Thomson Reuters in Collaboration with DinarStandard. (2017) State of the global Islamic economy report 2016/2017) [Online]. Available at:

https://ceif.iba.edu.pk/pdf/ThomsonReuters stateoftheGlobalIslamicEconomyReport201617.pdf (Accessed: 18 May 2018).

Ting, M. S., Goh, Y. N. and Isa, S. M. (2016) ‘Determining consumer purchase intentions toward counterfeit luxury goods in Malaysia', Asia Pacific Management Review, 21(4), pp. 219-230.

Tseng, S. C. and Hung, S. W. (2013) 'A framework identifying the gaps between customers' expectations and their perceptions in green products, Journal of Cleaner Production, 59, pp. 174-184.

Xu, Y., Chen, Y., Burman, R. and Zhao, H. (2014) 'Second-hand clothing consumption: a cross-cultural comparison between American and Chinese young consumers', International Journal of Consumer Studies, 38(6), pp. 670-677.

Yamin, S. and Kurniawan, H. (2011) A new generation of research data processing with Partial Least Square Path Modeling: Applications with XLSTAT Software, SmartPLS, and Visual PLS (Generasi Baru Mengolah Data Penelitian dengan Partial Least Square Path Modeling: Aplikasi dengan Software XLSTAT, SmartPLS, dan Visual PLS). Jakarta: Salemba Infotek.

Yazid, M. G. (2016) Designing a modest sportswear to provide comfort in daily sports activities for Muslim women wearing hijab [Online]. Available at: https://core.ac.uk/download/pdf/145798030.pdf (Accessed: 18 May 2018).

Zeithaml, V. A. (1988) 'Consumer perceptions of price, quality, and value: a means-end model and synthesis of evidence', The Journal of marketing, pp. 2-22. 
